\title{
Response Analysis of Nuclear Containment Structure Subjected to Dynamic Loads
}

\author{
Niteesh Halagatti ${ }^{\# 1}$, Rajashekar Swamy ${ }^{\# 2}$, Santhosh H P ${ }^{\# 3}$ \\ \#Civil Department, M.S Ramaiah University of Applied Science, Bangalore India \\ ${ }^{1}$ nitish.halagatti@gmail.com \\ ${ }^{2}$ rajashekharswamy.ce.er@msruas.ac.in \\ ${ }^{3}$ hpsanthosh.ce.er@msruas.ac.in
}

\begin{abstract}
Demand for energy is increasing day by day across the world resulting in construction of more number of atomic power stations. Critical facilities such as nuclear containment structure design require an exact and accurate assessment of aging requirements, because any failure of these facilities causes great threat to society.

In the present study nuclear containment structure is modelled according to specification of kudankulam nuclear containment structure and to carry out static analysis as well as dynamic analysis using both responses spectrum method and time history method for the same site location. In order to enhance the seismic safety of the nuclear containment structure Dynamic analysis is further carried out for synthetic earthquake (strong ground motion) by combining response spectrum and time history seismograph using time domain and frequency domain method. Lastly the seismic performance based design strain criteria of nuclear structure are evaluated for non-linear synthetic earthquake ground motion according to ASCE 41B chapter 6. The results obtained shows that the seismic base force is more for synthetic earthquake compared to equivalent static, response spectrum and time history and seismic performance strain criteria are within the permissible limit according to ASCE 41.
\end{abstract}

Keyword - Time history, response spectrum, Synthetic earthquake, Frequency domain, time domain, Performance based design, Life safety, Immediate occupancy, Collapse prevention.

\section{INTRODUCTION}

Increasing demand for nuclear energy across the world have increased concerns towards the safety of nuclear power plant as any basic harm to any these atomic reactors resulting in serious risk of radiation effects, real health issues and also organic and ecological dangers. As of May 2016, 444 nuclear reactors are operating across 30 countries for the production of electricity and 63 new nuclear power plants are in the construction phase in 15 countries. Across India Twenty atomic reactors with 4780 MW capacity are in operation and seven more reactors of $5300 \mathrm{MW}$ in construction stage.

An earthquake hazard has always been dependently danger to civil structures and maintaining the integrity of structures after and during an earthquake is essentially significance. The impact of this phenomenon is sudden without any traces of warning to make the arrangements for safety. Important projects such as Atomic power plant, thermal power plant, are designed to withstand earthquakes and to shut down safely during the event of a major seismic earthquake.

Across the world seismic prone plants are falls in Zone II and III except Narora atomic power plant in Uttar Pradesh, which is situated in Zone IV. Whereas Japan's nuclear plants falls in Zones VII, VIII and IX which shows that the Indian nuclear power plant are safer compared to Japan nuclear plants regions are categorized between Zones I and IX from least earthquake prone to most earthquake prone. Most of the Indian atomic power

Japan’s Fukushima Daiichi atomic power plant accident in 2011 In India nuclear power plants like kakrapur nuclear power plant, Tarapur nuclear power plant etc. is designed for lower intensity of earthquake. They could not withstand strong ground motion not even tsunami for example the Kalpakkam atomic power plant was flooded when tsunami hit coast of Tamil Nadu in 2004.”'These accidents increased fear from atomic reactors hence nuclear board is concentrating more on the seismic safety issues safety of the up-coming as well as old nuclear power plant.

The model building codes and regulation defines the minimum design requirements to ensure the safety of occupants during specific design events. Recent natural disasters led to admit that the building can meet the building codes, or even significant damage. After many natural disasters lot of schools, hospitals and infrastructure projects nuclear power plants has been closed, even if the damage is relatively small, required minimum code standards may not be sufficient to ensure continued functions. 


\section{BACKGROUND THEORY}

K. Kayvani, B. Schmidt, J. Steele, and G. Sidwell [6] in 2003 investigated the various aspects of Replacement Research Reactor Project (RRRP) using seismic engineering study of earthquake hazards, codal provisions, and design of shear wall, response spectrum and time history analysis using synthetically generated ground motion using SAP2000 and seismic qualification of the Reactor Block, and push over non-linear analysis for Reactor Building, results of this study reveals that Seismic hazardous study of PGA (Peak Ground

Acceleration) and DRS (Data reduction system) data of RRRP site found that during design earthquake local faults have lack of capability for the movement. The design criteria for reactor are that it should be within the elastic limit.

Nebojsaorbovic, timwiley, and marc boucho, [8] in year 2004 studied Seismic performance based evaluation of nuclear containment structures by developing a link between FEMA-356 (Federal emergency management agency) evaluation acceptance criteria in terms of DEO-1020 (Department of energy) risk reduction factors is used for the research. Allowable criteria for nominal structures are combined with probabilistic. Evaluation of seismic hazard and improved capacity-side fragility of structural components may form an acceptable framework for performance-based evaluation of existing nuclear facility structures. Finally authors conclude that In FEMA-350, the hazard levels, for any 50 year period, which are described by $2 \%$ and $10 \%$ recurrence probabilities are associated with the immediate occupancy Level and collapse prevention limit.

Neelima Satyam, O Divya [9] in 2011 studied Seismic analysis of nuclear containment structure by considering with and without soil structure interaction. Nuclear reactor is modelled and analysed using SAP2000 according to specification of Indian standards and at three floors displacement time history is determined and converted into response spectrum for fixed base condition with and without SSI. Authors conclude that finite element modelling and analysis of base raft mat foundation along with modelling of foundation soil gives more realistic results but is too complicate for everyday engineering applications

Ahmerali [1] in 2014 evaluated probabilistic seismic hazard analysis of Korean base isolated nuclear containment structure by considering time history parameter of Tohoku earthquake. Prototype lumped mass structural stick model of Korean NPP is developed to carry out the time history analysis. They concluded that the risk level is more for lower value of dominant PGAs for long period ground motion and ground motion with longer period time history are hazardous to NPP

Qiang X U [10] in 2015 carried out Design of shield building to protect the steel containment vessel of the nuclear reactor to ensure safety and integrity during natural calamities like earthquake and to study the effect of water in water tank due to the response of AP1000 shield building (Pressurized water reactor) during earthquake motion The results reveal that water level in the water tank can restrict the vibration of AP1000 shield building by fluid structure interaction Phenomena.

\section{III.METHODOLOGY}

Finite element modeling of nuclear containment structure is done using SAP 2000 according to specification of Kudankulam nuclear power plant project, which is located along the gulf coast of Mannar at 25km northeast of Kanyakumari India, due to some short falls further analysis is carried out using ETABS.

Earthquake analysis is generally carried out by two method namely equivalent static earthquake analysis method and dynamic analysis. Dynamic analysis is further classified into response spectrum method or time history method. Background theory reveals that dynamic analysis study for nuclear containment structure is done either by time history method and response spectrum method. In the present case non-linear dynamic analysis study is carried out by generating artificial earthquake by matching response spectrum generated using IS 1893 (part 1) 2002 and California state time history seismograph, using two frequency domain method and time domain method. Generated seismograph loads are applied to nuclear containment structure to carry out dynamic seismic analysis.

\section{IV.NUMERICAL MODELING}

Numerical modelling of the Kudankulum containment structure has been developed using finite element based program software named as SAP 2000 as shown in figure 1. Four nodded three dimensional quadrilateral thin shell elements having six DOF are used to develop a nuclear containment structure finite element model. Thin shell element considers both in-plane and out- plane stiffness during the analysis. Totally 1875 nodes and 1850 thin shell elements are used for modelling of super structure.

\section{A. Nuclear containment specifications}

$\begin{array}{ll}\text { Height of the nuclear vault above ground level } & : 64.5 \mathrm{~m} \\ \text { Height of the nuclear vault below ground level } & : 9 \mathrm{~m} \\ \text { Diameter of the Vault } & : 50 \mathrm{~m} \\ \text { Thickness of shear wall } & : 1.2 \mathrm{~m}\end{array}$




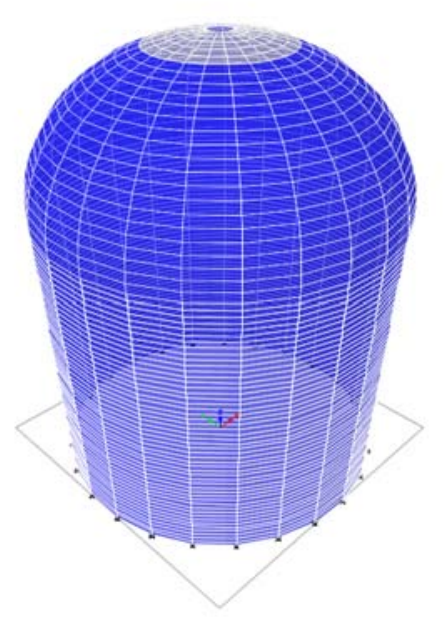

Figure 1: Numerical Nuclear Vault Model

\section{B. Material properties}

Elastic material model is used to simulate the structure of receiving material as an atomic regulation structure is designed to accommodate elastic limits based on the assumptions limit state criteria. Reinforcement shall be conforming to IS 1786. HYSD bars of Grade Fe550 and Concrete shall be confirming to IS 456 and OPC conforming to IS 12269 and aggregates confirming to IS 383 shall be used for concrete.

Table 1: Material Properties

\begin{tabular}{|l|l|l|l|l|c|l|}
\hline \multicolumn{1}{|c|}{ Name } & Type & symmetrical & \multicolumn{1}{|c|}{ E } & N & $\begin{array}{c}\text { Unit } \\
\text { Weight }\end{array}$ & $\begin{array}{c}\text { Design } \\
\text { Strengths }\end{array}$ \\
\hline & & Direction & $\mathrm{MPa}$ & & $\mathrm{kN} / \mathrm{m}^{3}$ & \multicolumn{1}{c|}{$\mathrm{Mpa}$} \\
\hline M60 & Concrete & Isotropic & 38729.83 & 0.2 & 24.9926 & $\mathrm{Fc}=60$ \\
\hline HYSD550 & Rebar & Uni-axial & 200000 & 0.3 & 76.9729 & $\begin{array}{l}\mathrm{Fy}=550, \\
\mathrm{Fu}=585\end{array}$ \\
\hline
\end{tabular}

Where,

E- Modulus of elasticity

N- Poisson's Ratio

\section{STATIC AND DYNAMic LoAdS}

\section{A. Dead loads}

Dead loads are considered according to IS 875 (PART 1)-1987 and according to density of possible dead loads. In the present study to reduce the complexity of calculation self-weight of structure is calculated by program itself.

\section{B. Earthquake and Wind parameters}

Equivalent static earthquake load and wind load parameters are taken as per the specification of kudunkulam Nuclear power plant site location according to I.S 1893 (Part 4) 2005 and I.S 875 (part 3) respectively, Kudunkulam Nuclear power plant falls in Zone II, But in the present study it is assumed as zone III as it is a very important structure and very closer to zone III. Seismic and wind parameters incorporated in the present study are tabulated below. 
Table 2 Earthquake and wind Parameters

\begin{tabular}{|l|c|l|}
\hline \multicolumn{1}{|c|}{ Parameter } & Values & \multicolumn{1}{c|}{ Reference } \\
\hline & 0.16 & From Table number 2 of IS 1893 2002 \\
\hline Zone factor (Z) & 3 & From Table number 3 of IS 1893 (Part4)2005 \\
\hline Reduction factor (R) & 2 & From Table 2 of IS 1893 (Part4) 2005 \\
\hline Importance factor ( I) & 2 & \multicolumn{2}{|c|}{ From table 1 of IS 1893 2002 } \\
\hline Soil Type Category & 1.67 & From 6.4.5 clause of IS 1893 2002 \\
\hline Seismic acceleration coefficient & 0.95 & Clause Number 7.6.2 of IS 1893 (Part1)2002 \\
\hline Time Period & Wind Parameters \\
\hline & $9.8 \mathrm{~m} / \mathrm{s}$ & Average wind speed at kudunkulam \\
\hline Wind speed & B & 5.3.2.1 clause of I.S 875 part 3 \\
\hline Structure Class & 2 & 5.3 .2 .1 clause of I.S 875 part 3 \\
\hline Terrain Category & 1 & 5.3.1 clause of I.S 875 part 3 \\
\hline Risk coefficient $\mathrm{K}_{1}$ & 1 & 5.3.3 clause of I.S 875 part 3 \\
\hline Topography coefficient $\mathrm{K}_{2}$ & \multicolumn{2}{|c|}{ Table 15 fig number b of I.S 875 part 3. } \\
\hline External Pressure Coefficient &
\end{tabular}

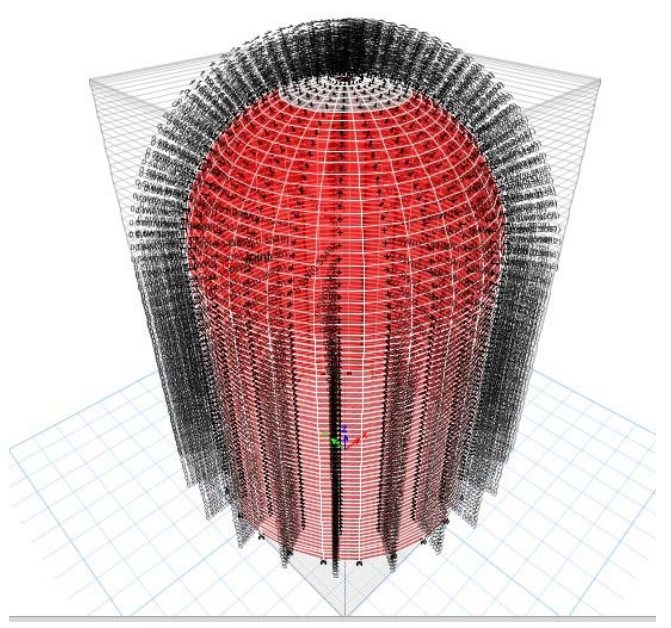

Figure 2: External Wind Pressure Coefficien

\section{VI.SYNTHETIC EARTHQUAKE GENERATION}

\section{A. RESPONSE SPECTRUM:}

According to I.S 1893 (part 1) 2002 [13] response spectrum is simply a plot of the peak or steady response (displacement, velocity or acceleration) of a series of oscillators of varying natural frequency that are forced into motion by the same base vibration. In the present study response spectrum parameters are defined using ETABS as per the specification of Kudunkulam Nuclear power plant site location according to I.S 1893 (Part 1) 2002 as shown in figure 3. Kudunkulam Nuclear power plant falls in Zone II, But in the present study it is assumed as zone III as it is a very important structure and very closer to zone III). 


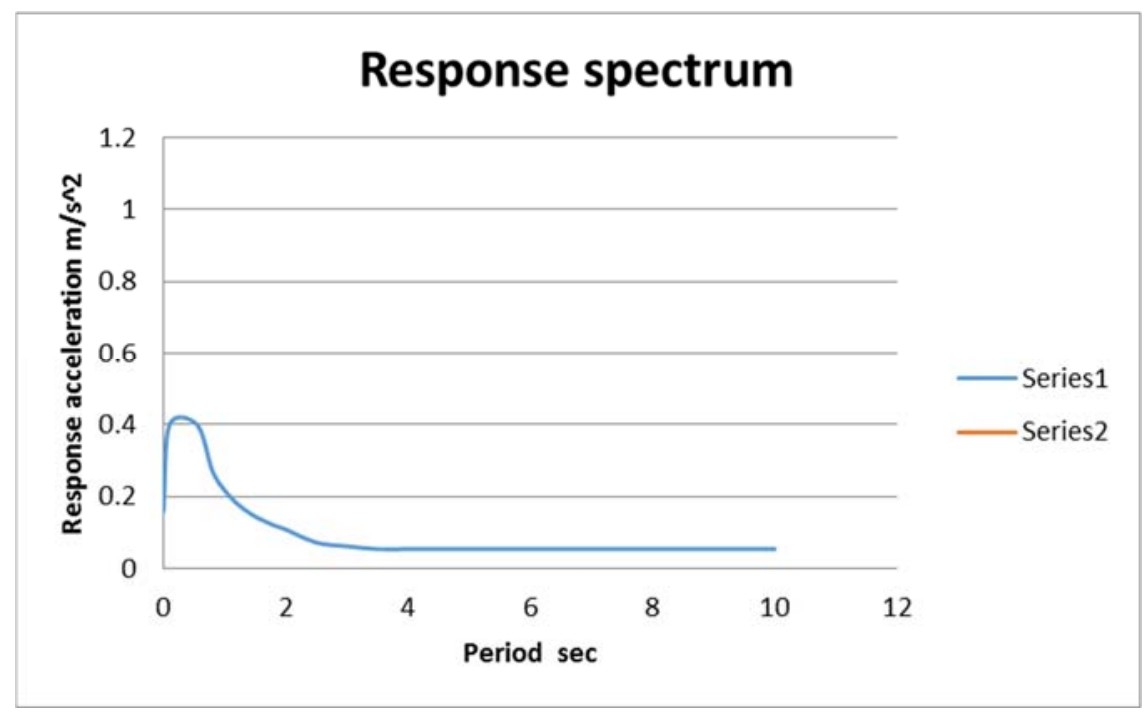

Figure 3 Response Spectrum

\section{B. Time history:}

According to IS 1893 Time history analysis is carried out using principles of dynamics based on an appropriate ground motion. It is an analysis used to determine the dynamic response of the structure when it is subjected to specific ground motion seismograph at each increasing set up of time. Past earthquake recorded seismograph data can be used for time history analysis. In present case El Centro California state time history seismograph is used as shown in figure 4

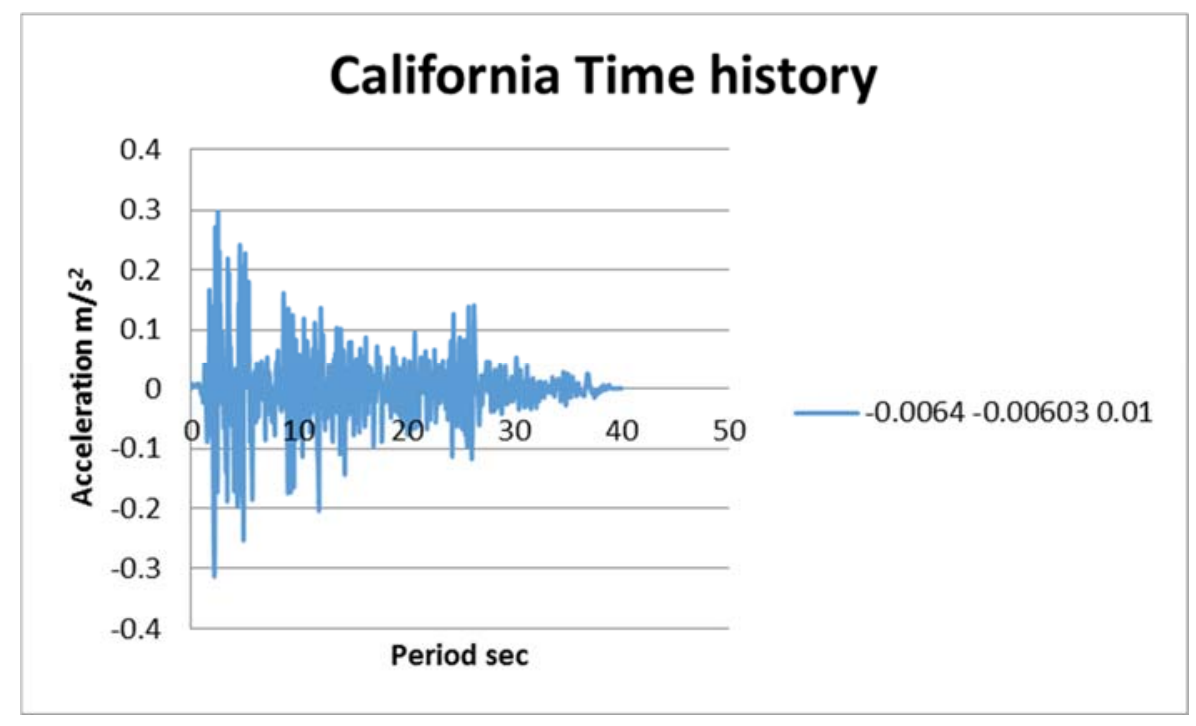

Figure 4 California State Time History

\section{Synthetic Earthquake:}

An engineered seismogram is the consequence of forward displaying the earthquake response for a mathematical earth model and it is characterized as far as 1D, 2D or 3D varieties in physical propertiesSpectrum-compatible time history functions are generated by modifying a defined time Series in the frequency domain or time domain method. Seismic input to nonlinear dynamic analyses of structures is defined in the form of acceleration time series (time-history function) whose response spectra are with a selected specific response spectrum curve. Different types of methods have been developed to change a reference time history function responses are compatible with a defined response spectrum. Two of the most widely used methods are frequency domain method \& the time domain method.

1) Frequency domain:

This method modifies the Fourier amplitude spectrum, based on the ratio of the target response spectrum to the responses of the time history function keeping the Fourier phase reference time history as constant. While this method is relatively straightforward, it does not generally have good convergence properties. Also, this approach often alters the varying character of the time history function in a large extent so that it no longer looks 
like a time series from an earthquake. Spectrum matching in this method invariably tends to increase the total energy in the ground motion. Generation of synthetic earthquake using frequency domain is shown in below figure

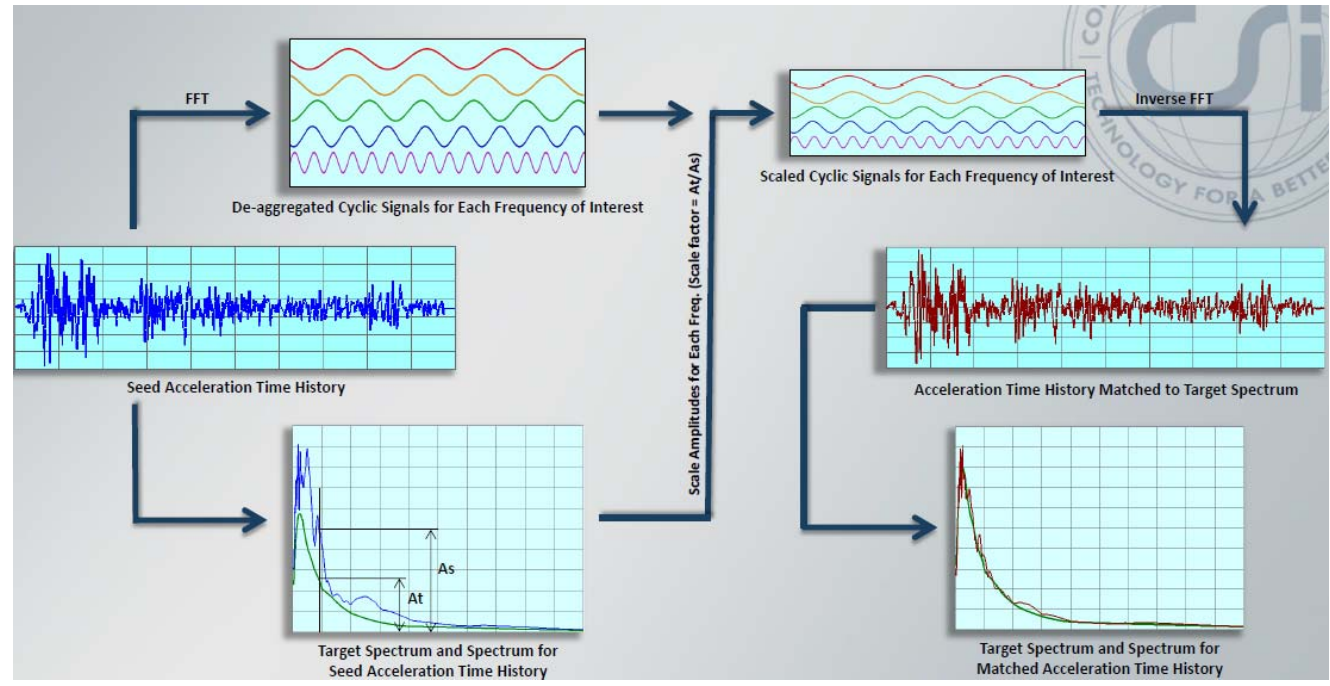

Figure 5 Frequency Domain Flow Chart

2)

Time domain method:

The time domain method was first introduced Lilhanand and Tseng (1987, 1988). Lilhanand proposed an algorithm that uses reserve impulse wavelet functions to modify the initial time histories such that its response spectrum is compatible with a specified target response spectrum. A fundamental assumption of this methodology is that there is no change in the time period of maximum response due to the adjustment of wavelet functions and it is not always valid as there will be shift in time period of peak response by alterations of the wavelet functions to the acceleration time history.

This method is considered as a good approach for synthetic earthquake generation since it changes the acceleration time histories function in the time domain by adding wavelets. A wavelet is a mathematical function that defines a waveform of effectively limited duration which has a zero average. The amplitude of the wavelet generally commences at zero, increases and finally returns back to original position. While the time domain spectral matching procedure is more difficult than other approach but it has good convergence properties and it saves the varying character of the reference time history function (time history data used for study) for most of the cases.

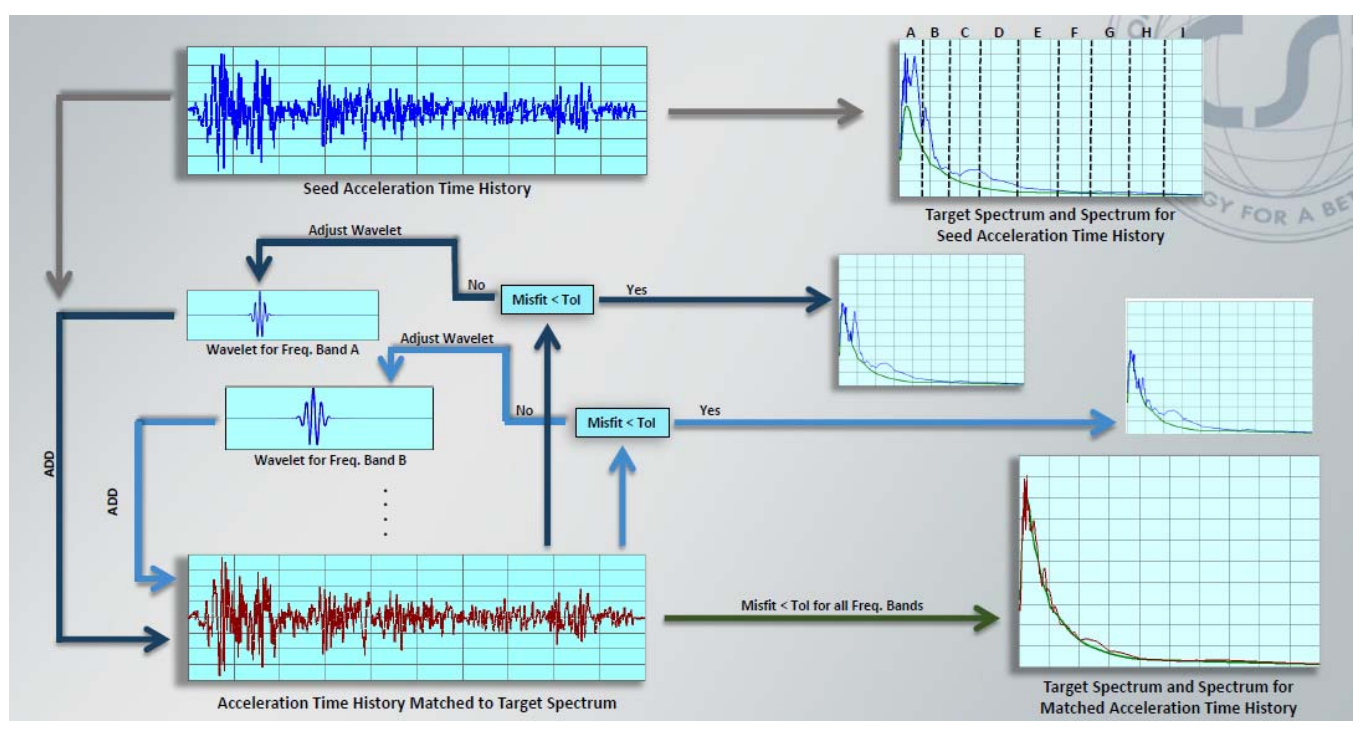

Figure 6 Time Domain Flow Chart 
D. $\quad$ Synthetic earthquake generation using ETABS

1) Response spectrum parameters:

Response spectrum loads are defined in both global $\mathrm{x}$ and global $\mathrm{y}$ direction, scale factor for response spectrum is chosen based on 7.8.2 clause of IS I893 2002. Response spectrum parameters used in the present study are shown in table number 3.

Table 3. Response Spectrum Parameters

\begin{tabular}{|l|l|l|}
\hline Response spectrum parameters & \multicolumn{2}{c|}{ Coordinate directions } \\
\hline \multicolumn{1}{|c|}{ Defined in ETABS } & \multicolumn{1}{c|}{ Global $\mathrm{x}$} & \multicolumn{1}{c|}{ Global $\mathrm{y}$} \\
\hline Name & Spec $\mathrm{x}$ & Spec $\mathrm{Y}$ \\
\hline Mass Source & Earthquake & Earthquake \\
\hline Load Type & Acceleration & Acceleration \\
\hline Load Name & U1 & U2 \\
\hline Function & IS 1893 & IS 1893 \\
\hline Scale Factor & 3102.22 & 3102.22 \\
\hline Modal Case & Modal & Modal \\
\hline Modal Combination & CQC & CQC \\
\hline Include Rigid & N0 & N0 \\
\hline Directional Combination & SRSS & SRSS \\
\hline Design Load Type & Response spectrum & Response spectrum \\
\hline Constant Damping & 0.05 & 0.05 \\
\hline
\end{tabular}

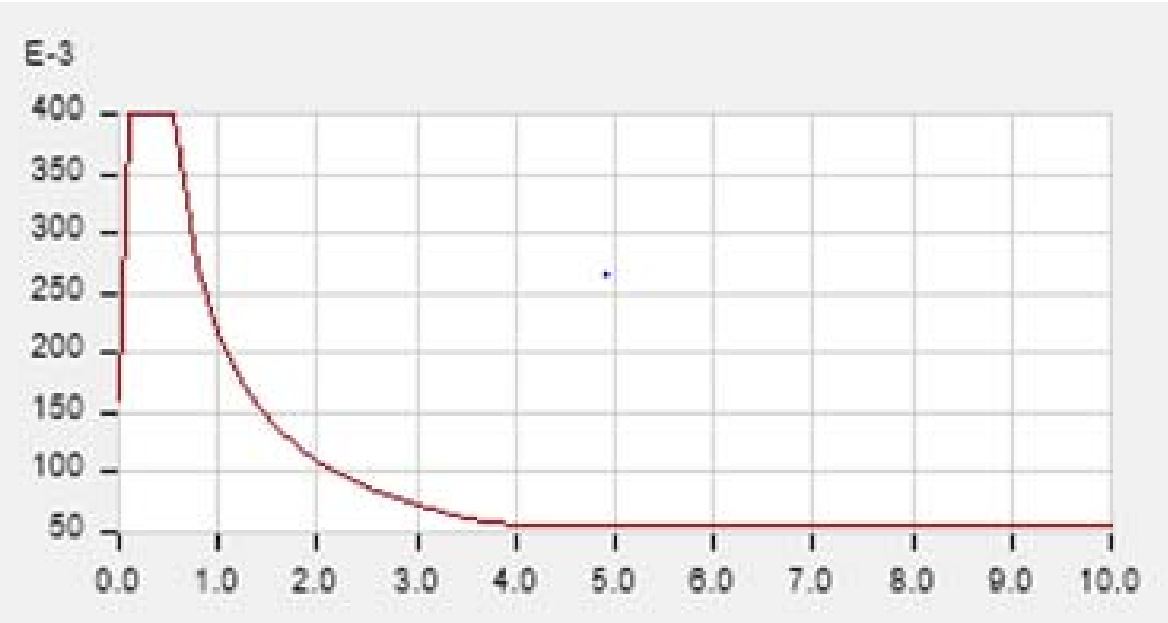

Figure 7 Response Spectrum Curve Obtained In Etabs Response acceleration vs. period

2) Time history

California state time history function defined in ETABS is shown in below figure

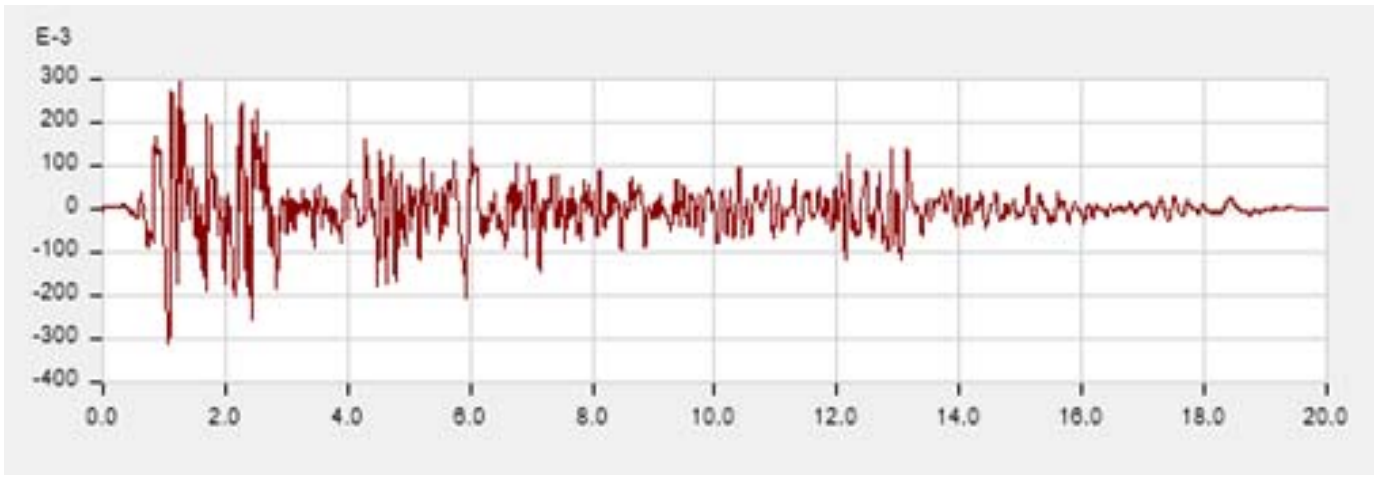

Figure 8 California State Seismographs 


\section{3) Synthetic earthquake}

a) Frequency domain:

- Initially Spectral Matching in Frequency Domain function is selected

- $\quad$ Defined target response spectrum based on IS 18932002 and reference time history function are selected

- The frequency range for which the spectral matching as to done is selected for the entire frequency range $(0.01 \mathrm{~Hz}$ to $100.0 \mathrm{~Hz})$.

- $\quad$ Click "match Time History" to generate the new time series.

Generated earthquake seismograph using frequency domain method is shown in the below figure 30 in which grey colour indicates response spectrum curve, blue colour indicates the El Centro California state seismograph, Red colour indicates the stimulated earthquake.

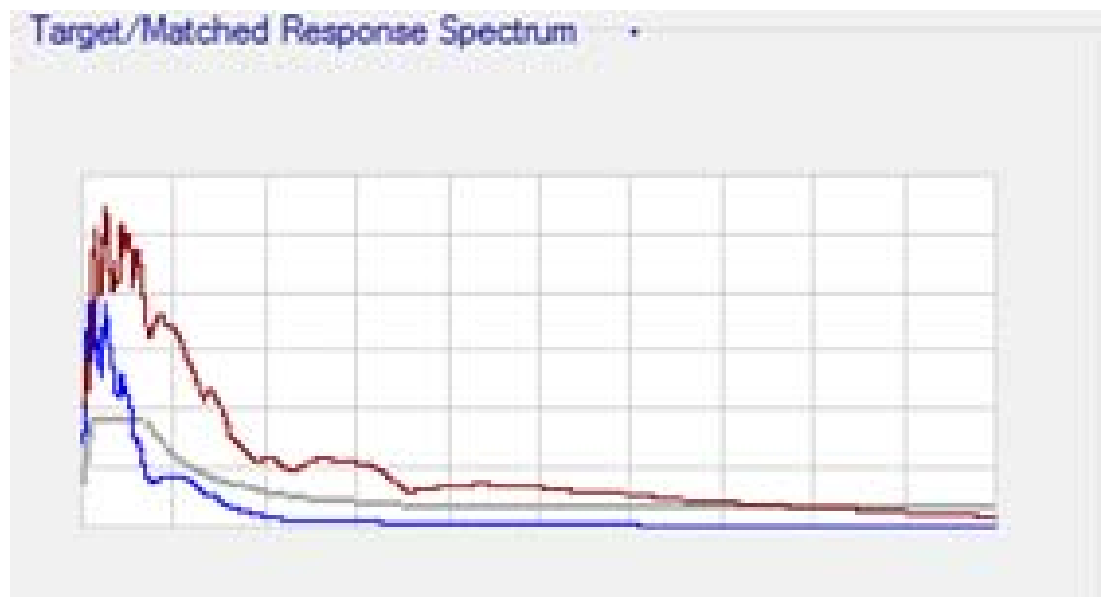

Figure 9Traget Matched Response Spectrum

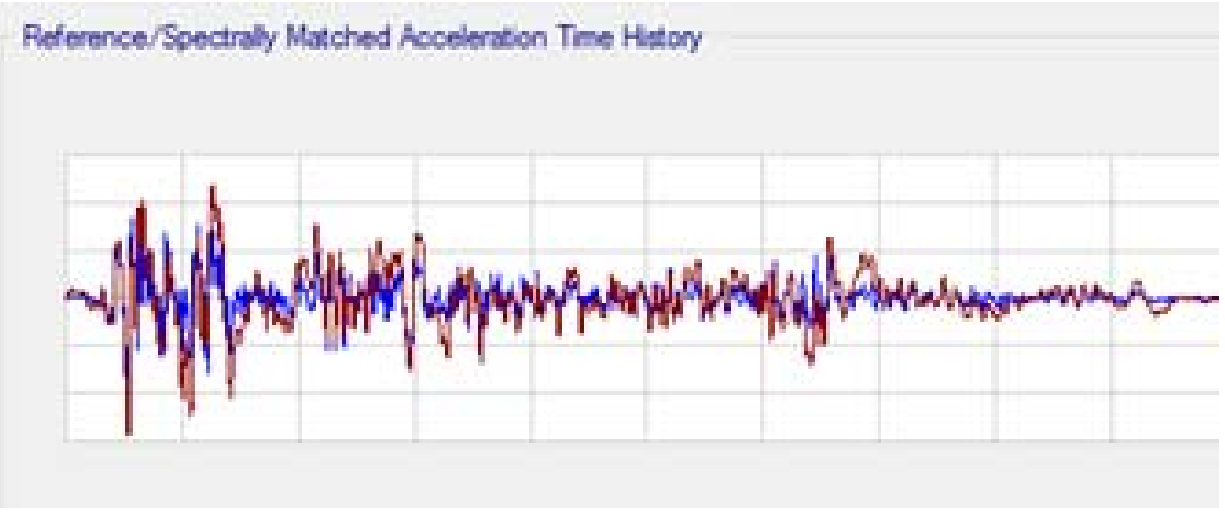

Figure 10 Reference Matched Acceleration Time History

b) Time domain

- Initially Spectral Matching in Frequency Domain function is selected

- Defined target response spectrum based on IS 18932002 and reference time history function are selected

- The frequency range for which the spectral matching as to done is selected for the entire frequency range $(0.01 \mathrm{~Hz}$ to $100.0 \mathrm{~Hz})$.

- Specify the number of recursions and the recursion factor for the spectral matching in time domain. Since the short period accelerations are influenced by the long period wavelets, spectral matching is done in multiple recursions (passes). Only the range smaller period of the response spectrum is matched in the first recursion. Matching of long period range of the spectrum occurs in subsequent recursions. The recursion factor $(>=1.0$ and $<=2.0)$ dictates the selection of time period range for recursions following the initial recursion.

- $\quad$ Click "match Time History" to generate the new time series. 
Stimulated earthquake seismograph is shown in the below figure in which grey colour indicates response spectrum curve, blue colour indicates the El Centro California state seismograph, Red colour indicates the stimulated earthquake.

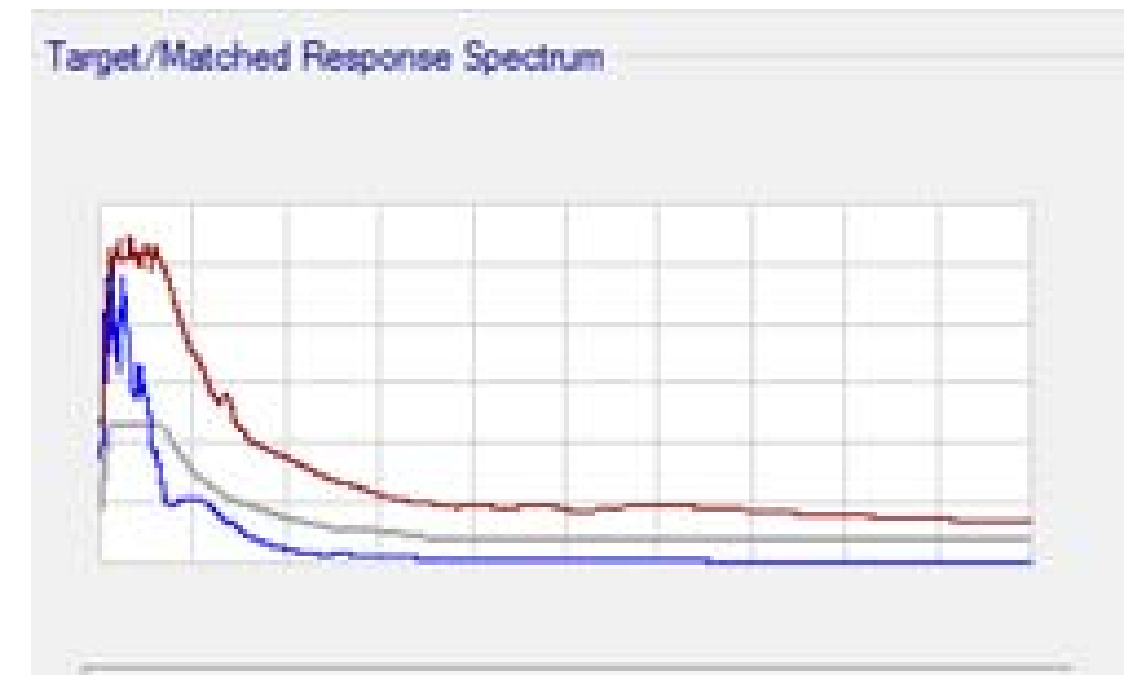

Figure 11 Target Matched Response Spectrum

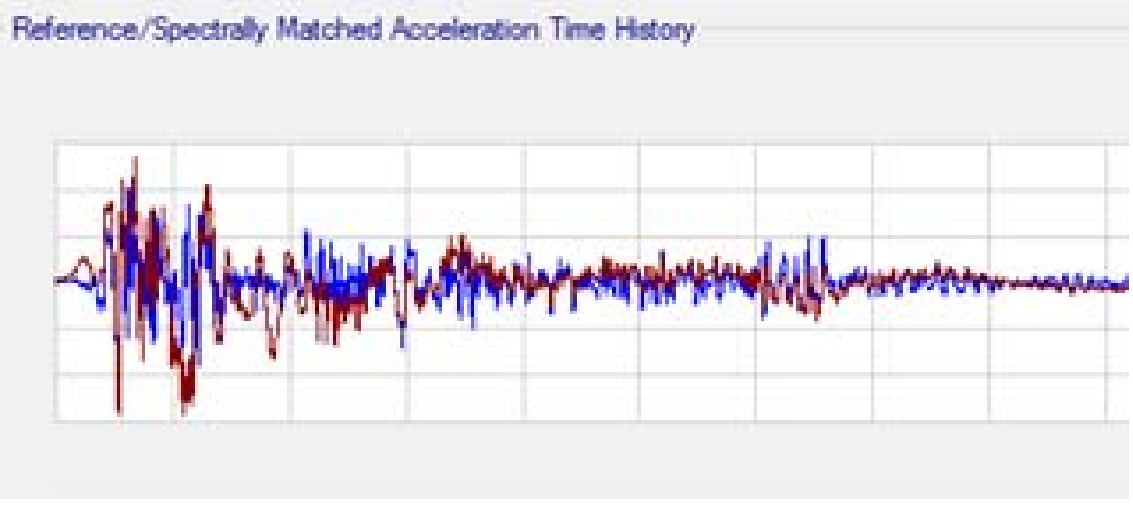

Figure 12 Reference Matched Acceleration Time History

Table 4 Load Cases

\begin{tabular}{|l|c|c|c|c|c|c|}
\hline \multirow{2}{*}{$\begin{array}{c}\text { Time history } \\
\text { load parameters }\end{array}$} & \multicolumn{2}{|c|}{ Time History } & \multicolumn{2}{c|}{ Time History Synthetic_Freq } & \multicolumn{2}{c|}{ Time History Synthetic_time } \\
\cline { 2 - 8 } & $\mathrm{x}$ & $\mathrm{y}$ & $\mathrm{X}$ & $\mathrm{Y}$ & $\mathrm{X}$ & $\mathrm{Y}$ \\
\hline Mass source & Earthquake & Earthquake & Earthquake & Earthquake & Earthquake & Earthquake \\
\hline Load type & Acceleration & Acceleration & Acceleration & Acceleration & Acceleration & Acceleration \\
\hline Load name & $\mathrm{Ux}$ & $\mathrm{Uy}$ & $\mathrm{Ux}$ & $\mathrm{Uy}$ & $\mathrm{Ux}$ & Uy \\
\hline Function & $\begin{array}{c}\text { California } \\
\text { State }\end{array}$ & $\begin{array}{c}\text { California } \\
\text { State }\end{array}$ & Synthetic_Freq & Synthetic_Freq & Synthetic_time & Synthetic_time \\
\hline Scale Factor & 3102.22 & 3102.22 & 3102.22 & 3102.22 & 3102.22 & 3102.22 \\
\hline Time Factor & 1 & 1 & 1 & 1 & 1 & 1 \\
\hline $\begin{array}{l}\text { Arrival Time in } \\
\text { Sec }\end{array}$ & 0 & 0 & 0 & 0 & 0 & 0 \\
\hline $\begin{array}{l}\text { Geometric } \\
\text { Non-linearity }\end{array}$ & P-delta & P-delta & P-delta & P-delta & P-delta & P-delta \\
\hline $\begin{array}{l}\text { Number of } \\
\text { output steps }\end{array}$ & 100 & 100 & 100 & 100 & 100 & 100 \\
\hline Step Size & 0.02 & 0.02 & 0.1 & 0.1 & 0.1 & 0.1 \\
\hline $\begin{array}{l}\text { Design Load } \\
\text { Type }\end{array}$ & \multicolumn{7}{|c|}{ Non-linear Direct Integration Method } \\
\hline
\end{tabular}




\section{PERFORMANCE BASED DESIGN}

Prescriptive or specification-based design focus attention on the "input", or the materials, methods and loads required whereas the PBD is the "output," or belief and building of the main users and stakeholders requirement.

In past seismic performance based design is carried out only for R.C.C framed structure in the present study performance based design is applied to nuclear containment structure according FEMA 451B [16] and ASCE 41[10] using CSI ETABS

According to International code council performance code performance-based design is "Agreed on the basis of an engineering design approach on performance goals and objectives, elemental analysis and engineering design goals and objectives of the use of alternatives accepted engineering tools, methods and performance criteria for quantitative assessment of the building."

The process takes into account the potential impact of actual response and performance of these systems and to assess the magnitude of building systems to quantify the frequency and potential events on the building function of inherent uncertainty.

The important goal of performance based design is that when varying levels of hazards are subjected by the building it performs in such way that it is within non-linear acceptance criteria mainly Operational, immediate occupancy, life safety and collapse prevention.

For performance-based seismic design, the performance levels described in ASCE 41 and FEMA 451B are summarized below and allow specification of an overall performance level by combining the desired structural performance with a desired non-structural performance.

\begin{tabular}{|c|c|c|c|c|c|c|}
\hline \multirow[b]{2}{*}{ 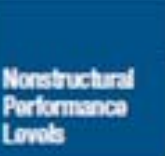 } & \multicolumn{6}{|c|}{ Structural Performance Levels and Panges } \\
\hline & $\begin{array}{c}\text { S-1 } \\
\text { Immediate } \\
\text { Occupancy }\end{array}$ & $\begin{array}{c}\text { S-2 } \\
\text { Damage } \\
\text { Control Range }\end{array}$ & $\begin{array}{c}\text { S-3 } \\
\text { Life } \\
\text { Safoty }\end{array}$ & $\underset{\text { Pange }}{\mathrm{S}-4}$ & $\begin{array}{c}\text { S-5 } \\
\text { Collspes } \\
\text { Prevention }\end{array}$ & $\begin{array}{l}\$-6 \\
\text { Not } \\
\text { Considered }\end{array}$ \\
\hline $\begin{array}{l}\text { NA } \\
\text { Operational }\end{array}$ & $\begin{array}{l}\text { Operational } \\
\text { 1-A }\end{array}$ & $2-A$ & $\begin{array}{c}\text { Not } \\
\text { Fecormmended }\end{array}$ & $\begin{array}{c}\text { Not } \\
\text { Recommended }\end{array}$ & Not & $\begin{array}{c}\text { Not } \\
\text { Recommended }\end{array}$ \\
\hline $\begin{array}{l}\text { N-B } \\
\text { Immedate } \\
\text { Occupancy }\end{array}$ & $\begin{array}{c}\text { Immediste } \\
\text { Dccupancy } \$ B\end{array}$ & $2 \cdot-B$ & $3-B$ & $\begin{array}{c}\text { Not } \\
\text { Recomenended }\end{array}$ & Nat & Not \\
\hline $\begin{array}{l}\text { N-C } \\
\text { Ule Safety }\end{array}$ & rC & $2-\mathrm{C}$ & Lide Saloty 3-C & $4-C$ & $5-\mathrm{C}$ & $6-\mathrm{C}$ \\
\hline $\begin{array}{l}\text { N-D } \\
\text { Hamards } \\
\text { Reduced }\end{array}$ & $\begin{array}{c}\text { Not } \\
\text { Rescommended }\end{array}$ & 20 & 30 & $4-0$ & 5-D & 6-D \\
\hline $\begin{array}{l}\text { N-E } \\
\text { Not Considered }\end{array}$ & $\begin{array}{c}\text { Not } \\
\text { Flecommended }\end{array}$ & $\begin{array}{c}\text { Not } \\
\text { Plecommended }\end{array}$ & $\begin{array}{c}\text { Not } \\
\text { Fecommended }\end{array}$ & 4.E & $\begin{array}{c}\text { Collapse } \\
\text { Prevention } 5-\mathrm{E}\end{array}$ & $\begin{array}{c}\text { No } \\
\text { Rehabilitation }\end{array}$ \\
\hline
\end{tabular}

Figure 13ASCE 41 Structural Performance Levels

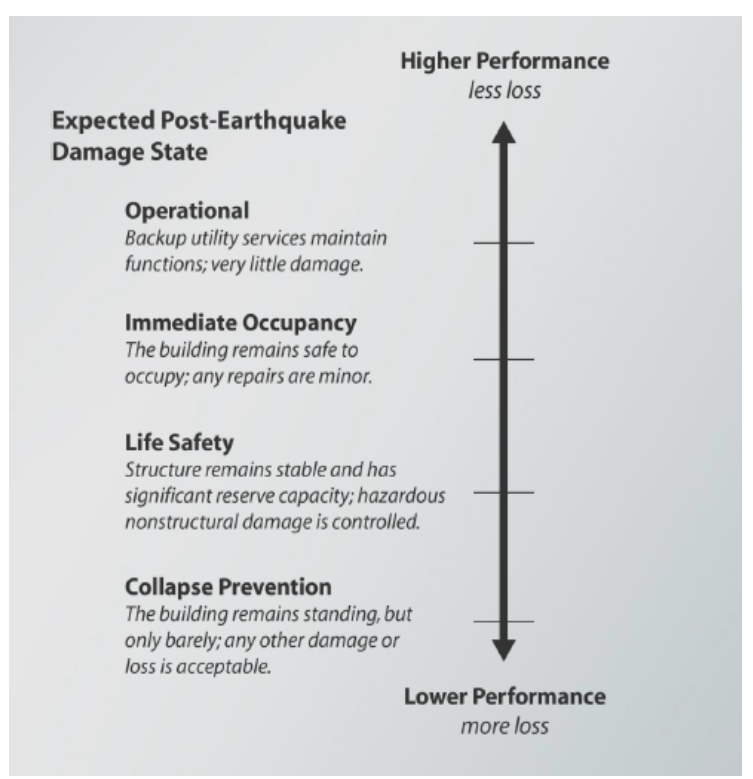

Figure 14 FEMA 451b Performance Levels 


\section{A. Steps for $P B D$}

- $\quad$ Perform initial analysis and design in sized member in determining reinforcement. Material properties should be used based on the strengths

- Identify components that should be detailed for non-linear behaviour so called deformation controlled component

- $\quad$ Perform an analysis using lower level earthquake like service basis earthquake using static equivalent method and response spectrum method make sure that the building remains primarily elastic.

- $\quad$ Perform an analysis by subjecting the building to larger earthquake like maximum considered earthquake using non-linear time history analysis (Synthetic earthquake) to determine the post steel behaviour of components.

- $\quad$ Compare the results to the appropriate acceptance criteria

\section{B. $\quad$ Performance based design using ETABS}

\section{Initially wall hinges are defined:}

Nonlinear force-displacement or moment-rotation behaviour are defined by hinge properties, it is fixed at the discrete points along the length of frame (line) objects or to the mid-height of wall objects. These are used during static non-linear static analysis, fast nonlinear analysis (FNA) modal time history analysis, and nonlinear direct integration time history analysis. The hinges behave has a rigid element and does not influence the behaviour of the member. The number of hinges not only affects computation time, but also the ease in which model behaviour and results may be interpreted. Therefore, it is strongly recommended that hinges be assigned only at locations where the occurrence of nonlinear behaviour is highly probable. The wall hinges are indicated by blue colour in the below figure 15 and figure 16

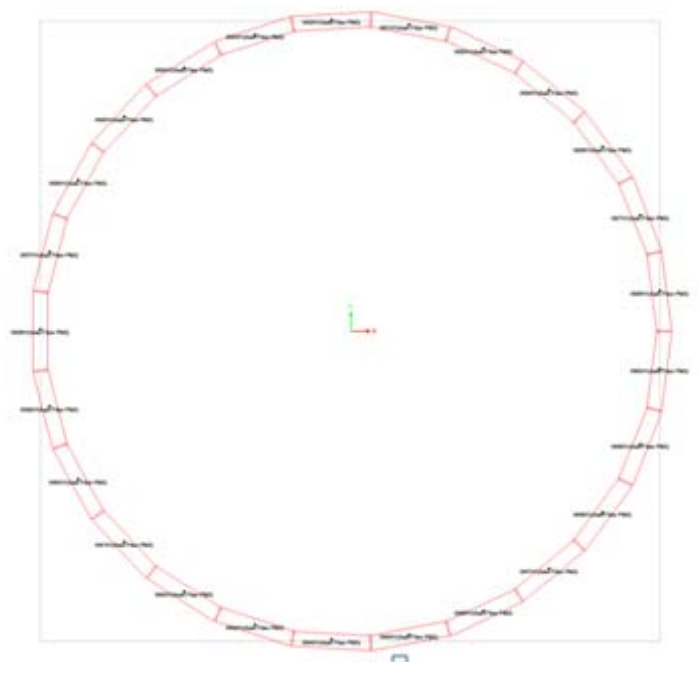

Figure 15Wall Hinges

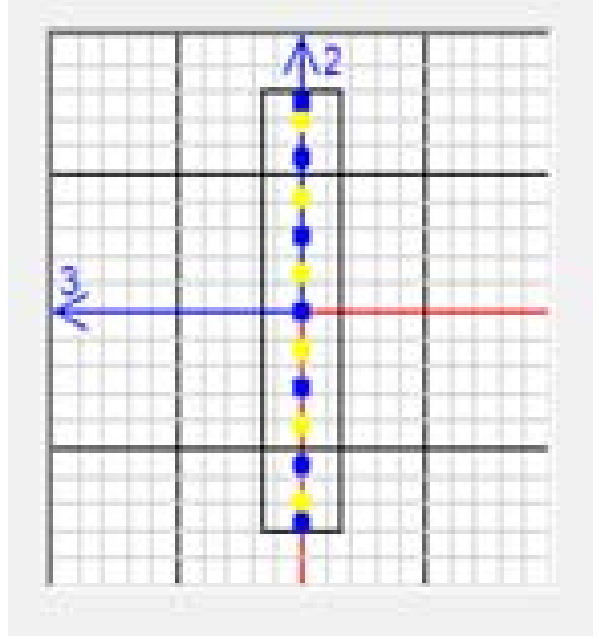

Figure 16: Shear Wall Hinges 
C. PBD Load Cases:

Table 5 PBD Load Cases

\begin{tabular}{|l|c|}
\hline Name & Type \\
\hline Dead & Linear static \\
\hline Live & Linear static \\
\hline Temp & Linear static \\
\hline EX & Linear static \\
\hline EY & Linear static \\
\hline WIND0 & Linear static \\
\hline WIND90 & Linear static \\
\hline Nonlinear TH response & Non-linear direct integration history \\
\hline Nonlinear TH response Synthetic_Freq & Non-linear direct integration history \\
\hline Nonlinear TH response Synthetic_Time & Non-linear direct integration history \\
\hline Specx & Response Spectrum \\
\hline Specy & Response Spectrum \\
\hline Long Term & Non-linear static staged Construction \\
\hline
\end{tabular}

VIII. RESULTS:

A. Synthetic Earthquake:

1) Base force:

Maximum Time history base force for California state earthquake is $50.9035 \mathrm{kN}$ occurring at $2.3 \mathrm{sec}$ as shown in figure 17

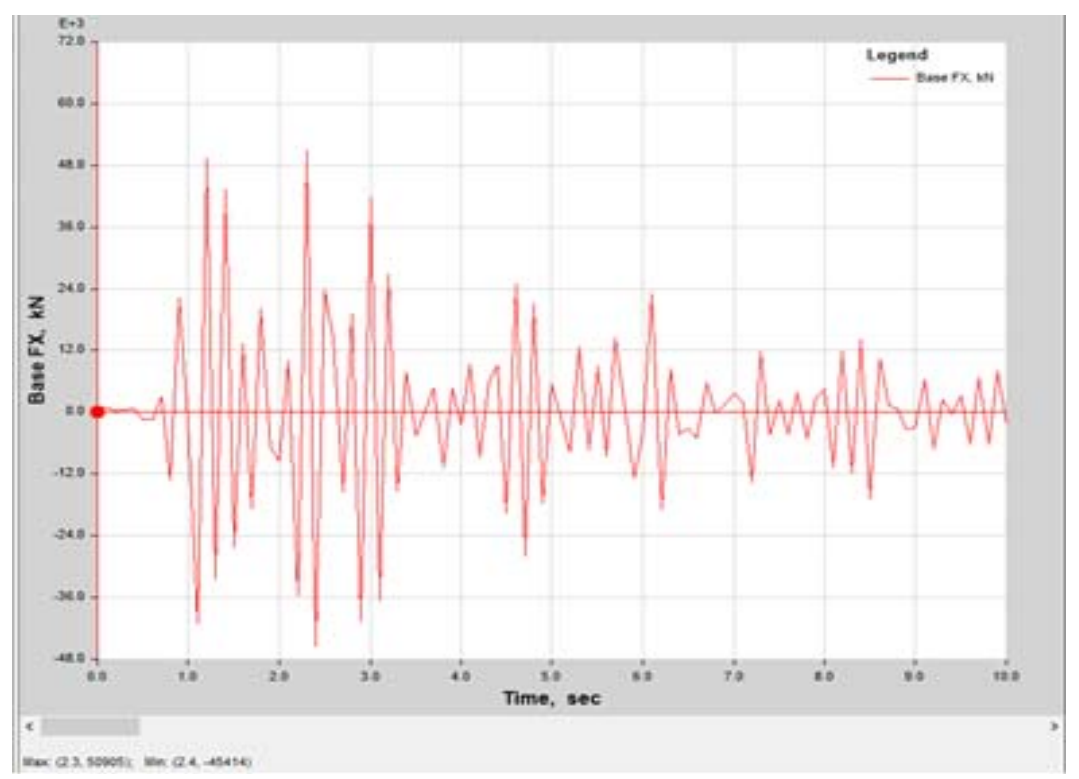

Figure 17 Time History Base Force for California State EQ

The maximum force is $79360 \mathrm{kN}$ at $1.2 \mathrm{sec}$ and minimum force is $-86827 \mathrm{kN}$ at $2.2 \mathrm{sec}$ for synthetic time domain method as shown in figure 18 


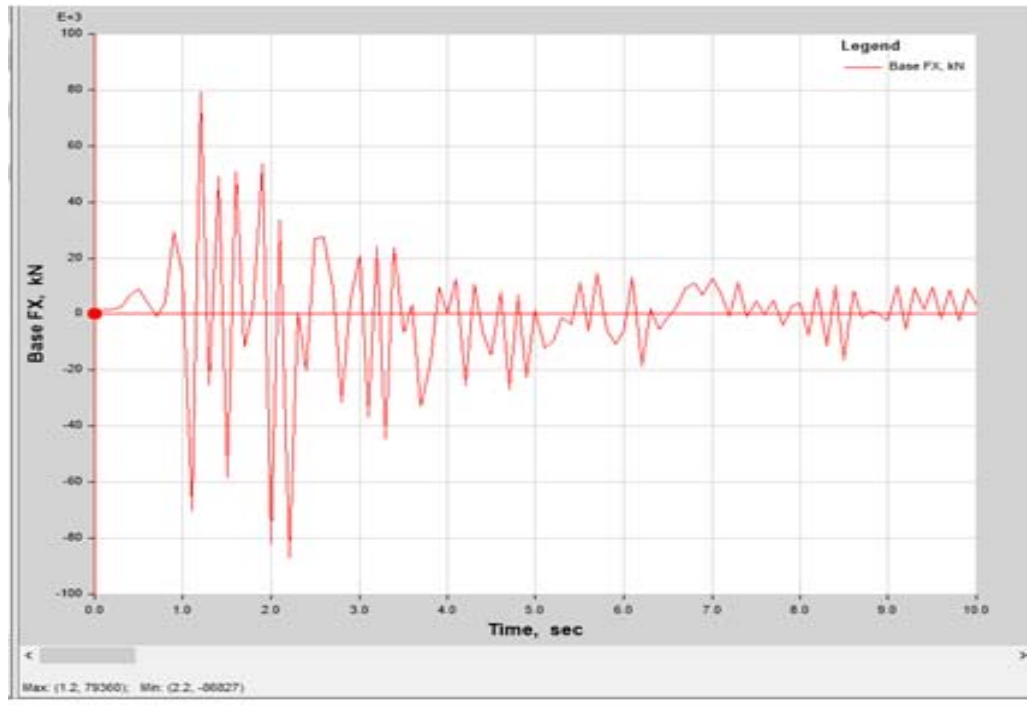

Figure 18 Base Forces For Synthetic Time Domain Method.

The maximum Base force is $65190 \mathrm{kN}$ at $1.2 \mathrm{sec}$ and minimum Base force is $-61594 \mathrm{kN}$ at $1.08 \mathrm{sec}$ for synthetic frequency domain method as shown in figure 19

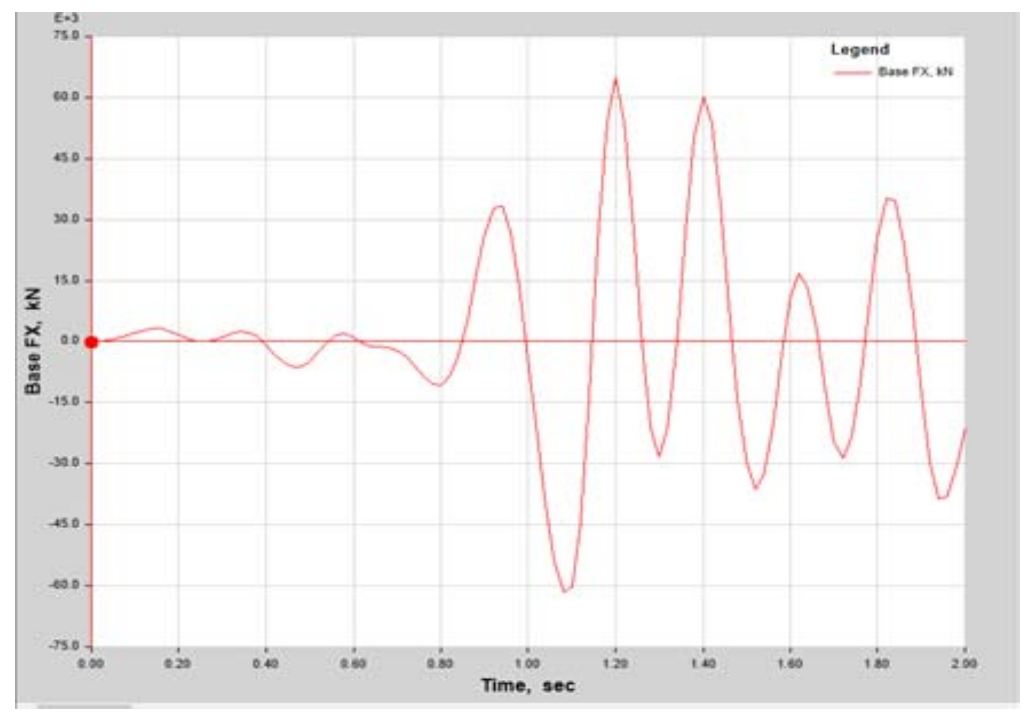

Figure 19 Base Force For Synthetic Frequency Domain Method

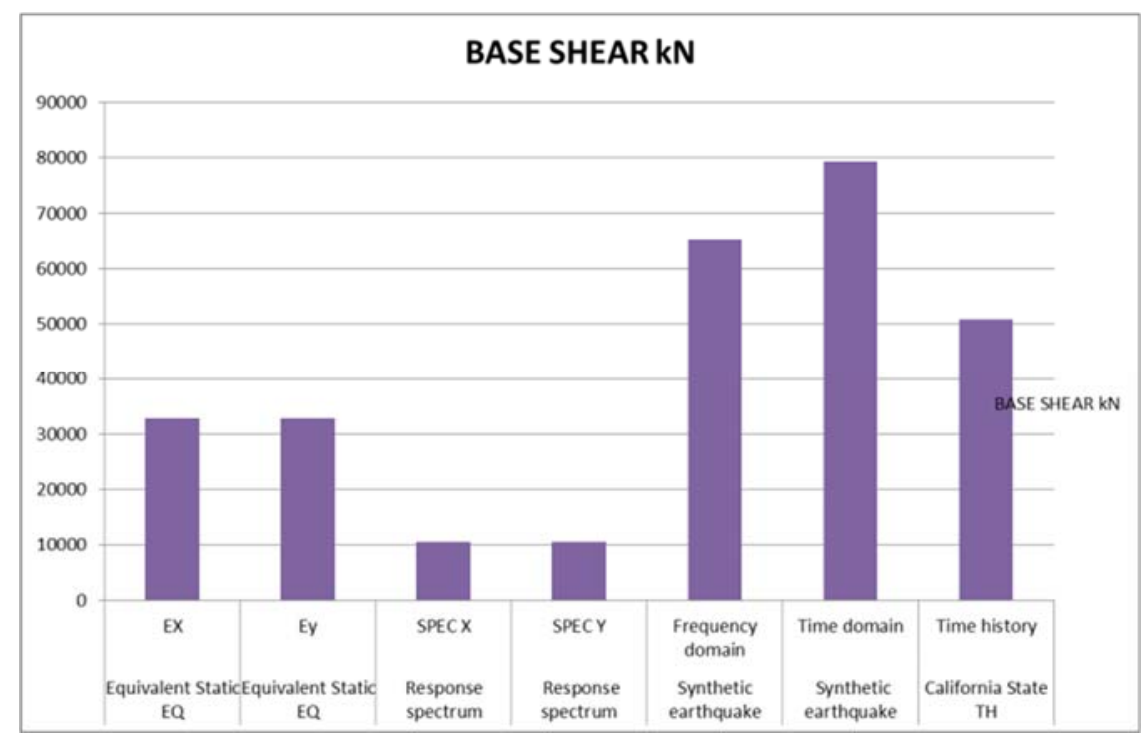

Figure 20:Comparison of Base Shears 
2) Story Displacement:

Maximum story displacement for California state earthquake is $3.175 \mathrm{~m}$ at storey 75 as shown in figure number 21

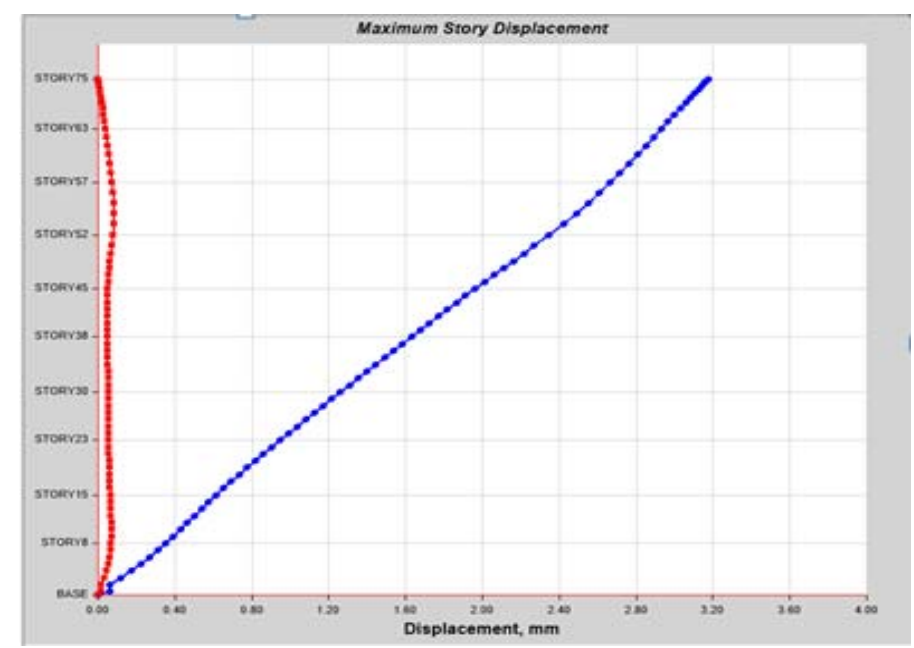

Figure 21Maximum Story Displacements for California State Earthquake

Maximum Story displacement found at storey 75 is $2.62 \mathrm{~mm}$ for equivalent static earthquake in X-direction as shown in below diagram. As the structure is symmetrical in nature maximum story displacement in $\mathrm{y}$ - direction is same as $\mathrm{x}$ - direction as shown in figure number 22

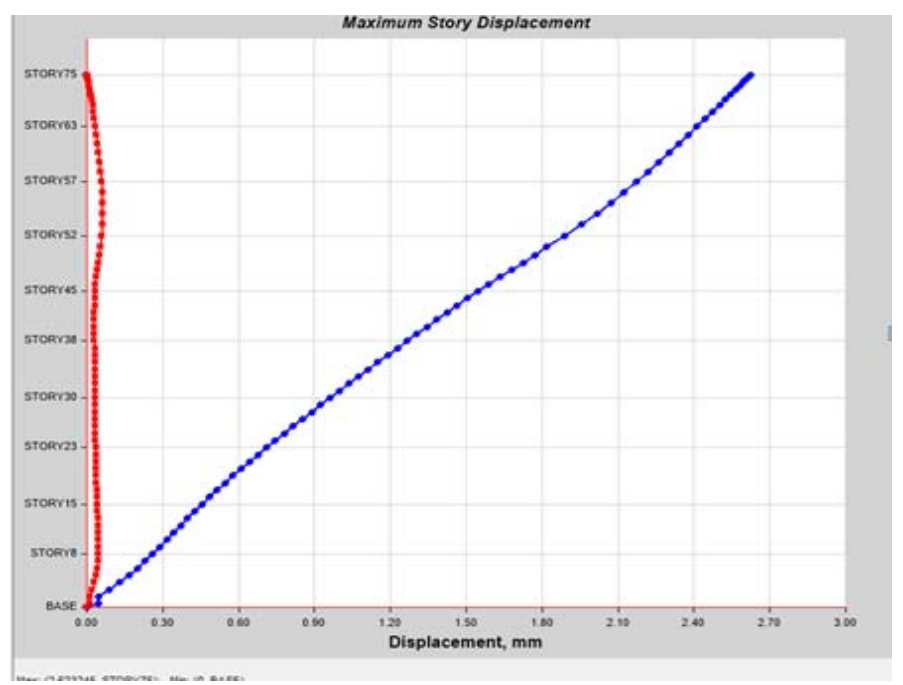

Figure 22: Maximum Story Displacement for Equivalent Static Earthquake

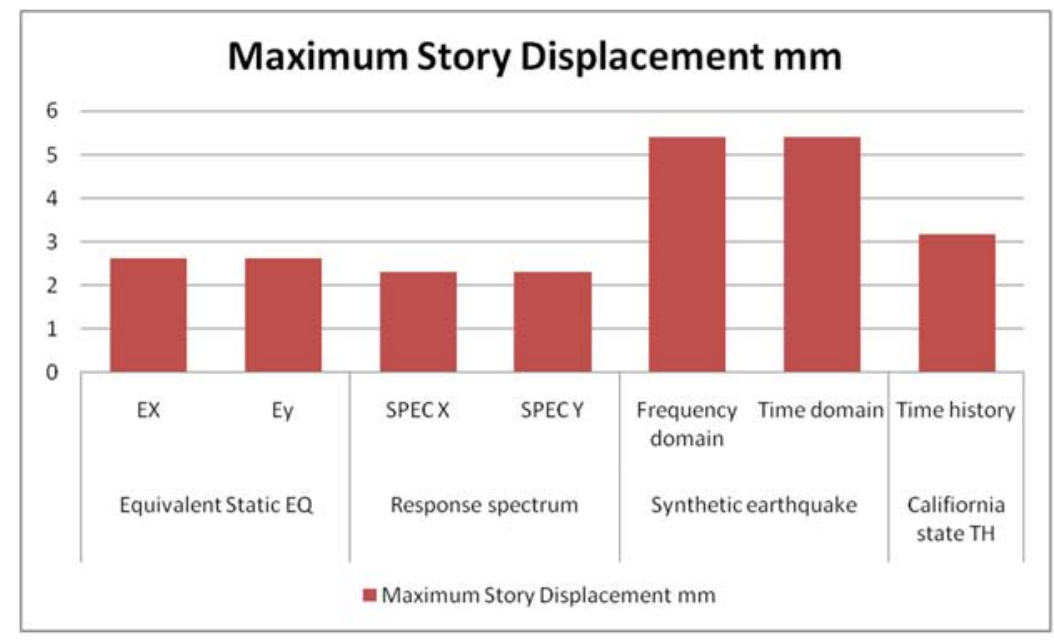

Figure 23: Comparison of Story Displacements 
B. $P B D$ :

1) Acceleration:

Maximum acceleration is $5354.488 \mathrm{~mm} / \mathrm{s} 2$ for $1.84 \mathrm{sec}$ time period and minimum acceleration is $-6699 \mathrm{~mm} / \mathrm{s} 2$ for $1.94 \mathrm{sec}$ time period for California State earthquake as shown in figure number 24

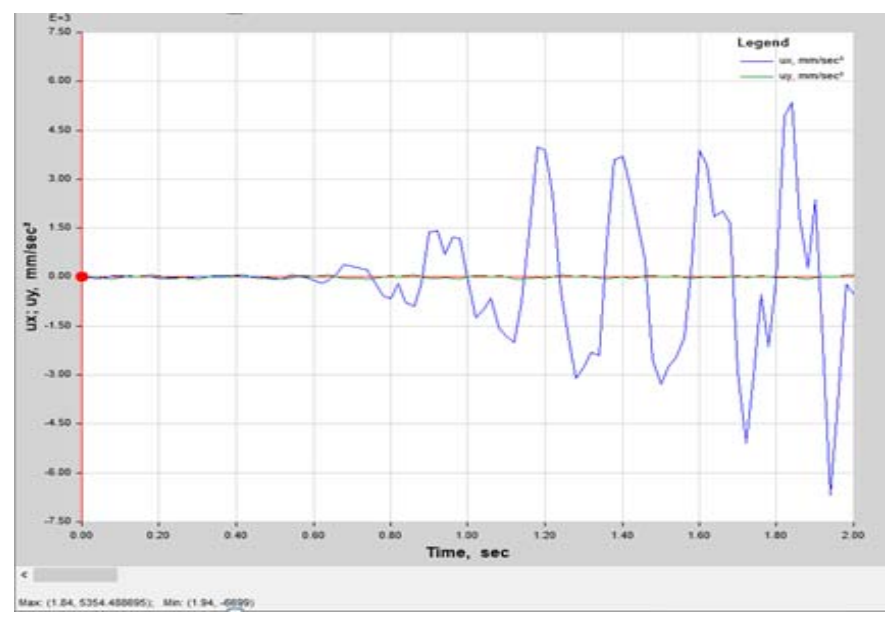

Figure 24: Maximum Acceleration for California State Earthquake

Maximum acceleration is $4337.6 \mathrm{~mm} / \mathrm{s} 2$ for $1.4 \mathrm{sec}$ time period and minimum acceleration is $-3293 \mathrm{~mm} / \mathrm{s} 2 \mathrm{for} 1.3$ sec time period for Synthetic Time domain earthquake as shown in figure number 25

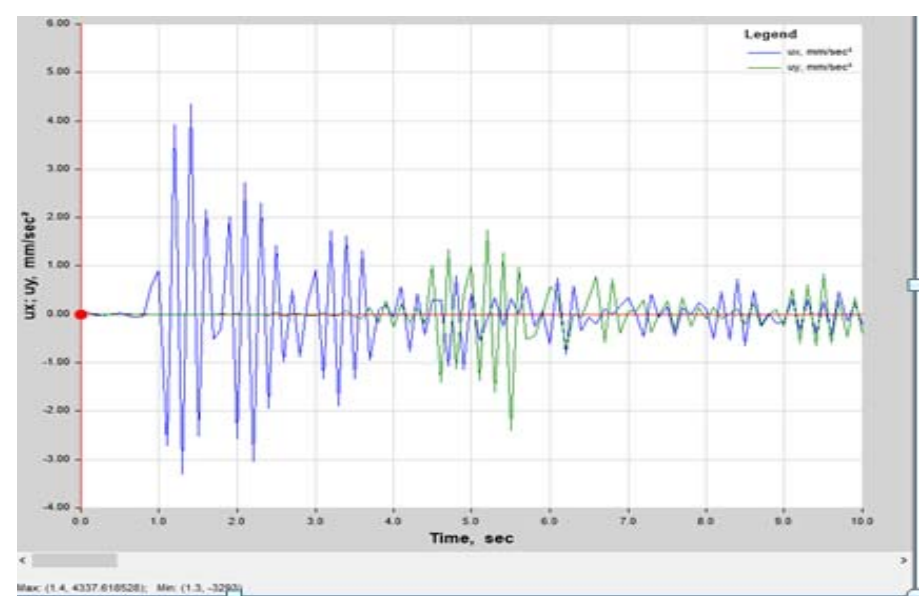

Figure 25:Maximum Acceleration for Synthetic Time Domain Earthquake

Maximum acceleration is $4303.37 \mathrm{~mm} / \mathrm{s} 2$ for $1.2 \mathrm{sec}$ time period and minimum acceleration is $-3603 \mathrm{~mm} / \mathrm{s} 2$ for $3.1 \mathrm{sec}$ time period for Synthetic Frequency domain earthquake as shown in figure number 26

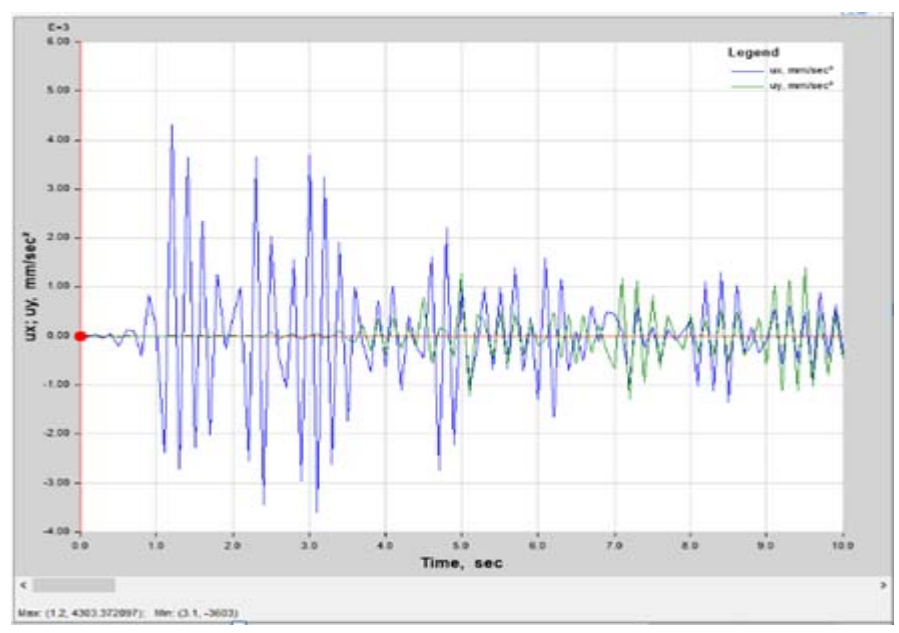

Figure 26: Maximum Acceleration for Synthetic Frequency Domain Earthquake 


\section{1) Strain limits:}

For Immediate occupancy Maximum strain value is 0.001 which is within the permissible value of strain i.e. 0.003 and 0.01 for both M60 and HYSD 550 respectively as shown in figure number 27

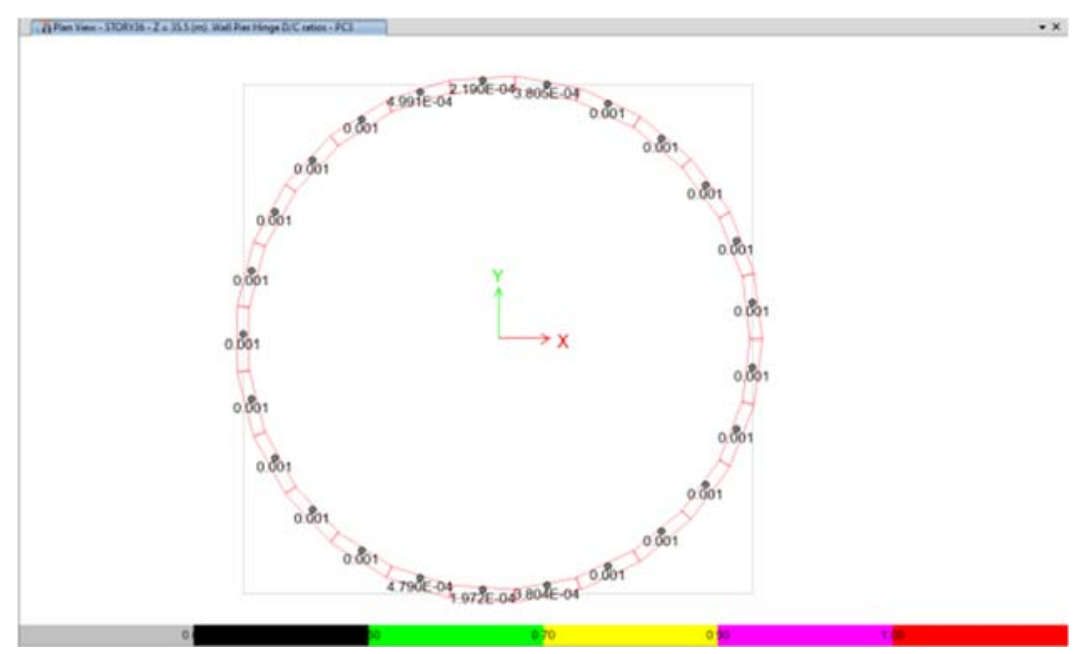

Figure 27Immediate Occupancy Strain Value

For Life safety Maximum strain value is 0.003 which is within the permissible value of strain i.e. 0.006 and 0.02 for both M60 and HYSD 550 respectively as shown in figure number 28

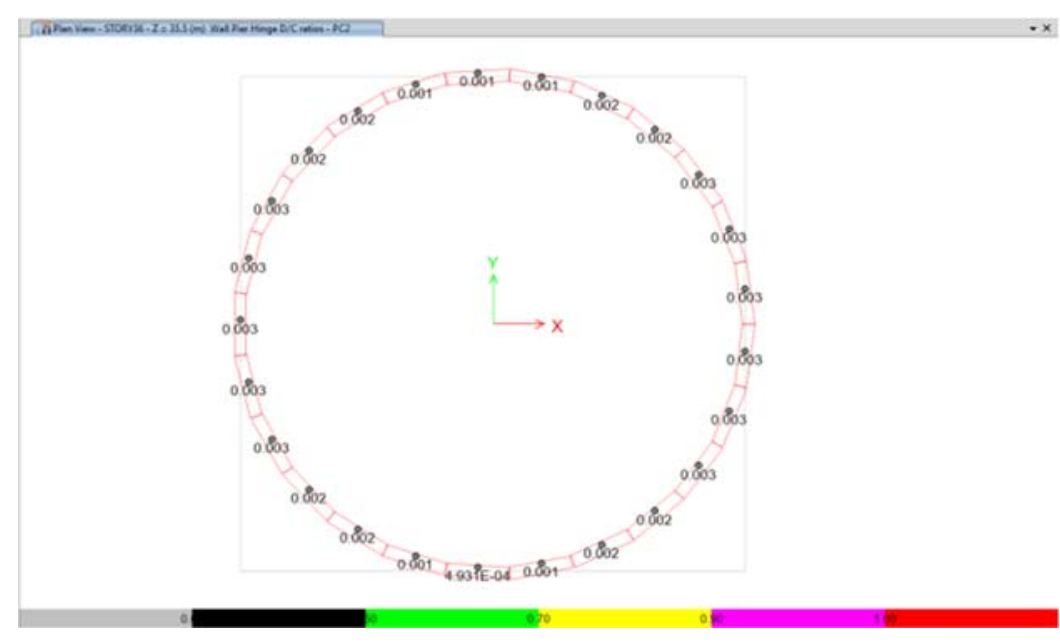

Figure 28Life Safety Strain Value

For Collapse prevention Maximum strain value is 0.006 which is within the permissible value of strain i.e. 0.015 and 0.05 for both M60 and HYSD 550 respectively as shown in figure number 29

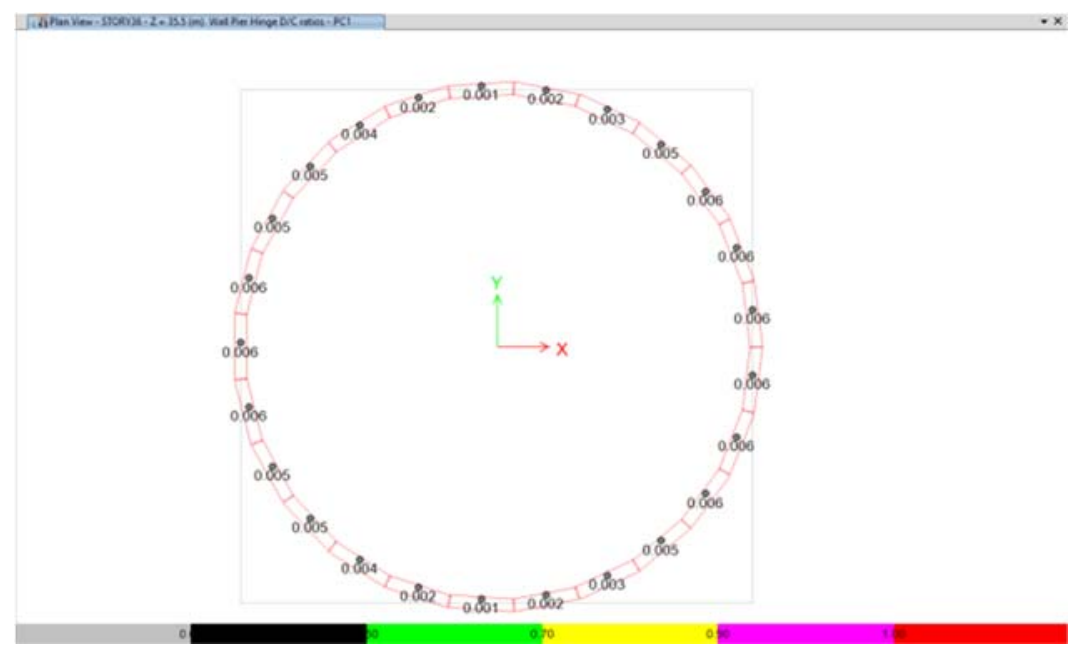

Figure 29Collapse Prevention Strain Value 


\section{CONCLuSION}

- Equivalent static methodbase shear and story displacement is more by amount of $18141.5 \mathrm{kN}$ and $0.575 \mathrm{~mm}$ respectively in comparison with response spectrum method time history method.

- In the Present study Compared to equivalent static method, response spectrum method and synthetic earthquake base shear and story displacement is more by amount of $28456 \mathrm{kN}$ and $2.225 \mathrm{~mm}$ respectively hence the nuclear vault is analyzed for strong earthquake ground motion.

- Synthetic earthquake Base shear is more by amount $14250 \mathrm{kN}$ for time domain method compared to frequency domain method, this shows that time domain method of generation of synthetic earthquake is accurate compared to frequency domain.

- Analysis of nuclear containment structure using time domain method was slow compared to frequency domain method.

- For immediate occupancy maximum strain value is 0.001 which is within the permissible value of strain i.e. 0.003 and 0.01 for both M60 and HYSD 550 respectively.

- For Life safety Maximum strain value is 0.003 which is within the permissible value of strain i.e. 0.006 and 0.02 for both M60 and HYSD 550 respectively.

- For Collapse prevention Maximum strain value is 0.006 which is within the permissible value of strain i.e. 0.015 and 0.05 for both M60 and HYSD 550 respectively

- Hence performance based design criteria are within the permissible limit according ASCE 41 chapter number 6

\section{ACKNOWLedgment}

I thank Mr. SANDEEP PINGALE MD E-construct Design and Build Pvt. Ltd for offering this project.

\section{XI.REFERENCES}

[1] Ahmer Ali, N. A. (2014). ProbalisticSiesmicAssesment Of Base Isolated NPPS Subjected To Strong Ground Motion Tohoku Earthquake. Department Of Civil And Environmental Engineering Korea, 8

[2] Antonio Ballesteros, R. S. (2014). Analyse Of Events Related To Cracks And Leaks In Rector Coolant Pressure Boundary. Nuclear Engineering And Design Elsevier, 5.

[3] G. Ruocci, P. B. (2012). Cracks Distance And Width In Reinforced Concrete. 15WCEE, (P. 10). LISB0V.

[4] HCC. (2014). Making Of Kudankulam Nuclear Power Plant .Kudanlulam .

[5] Howard Hwang, S. P.-W.-M. (2001). Generation Of Synthetic Ground Motion. USA: Board Of Trustees At The University Of Illinois.

[6] K. Kayvani, B. S. (2003). Seismic Engineering For Replacement Research Reactor In Australia. 2003 Pacific Conference on Earthquake Engineering, (P. 8). Australia.

[7] Kubo Tetsuo, N. S. (N.D.). Generation of Synthetic Earthquake Motions and Their Applications to Dynamic Analysis. Ibaraki Japan and Tokoyo: Research Engineering, Building Research Institute.

[8] Nebojsa ORBOVIC, B. S. (2004). Seismic Performance-Based Evaluation of Nuclear Facility Structures. 13th World Conference on Earthquake Engineering (P. 13). Canada: Vancouver, B.C

[9] NeelimaSatyam and O Divya, N. S. (2010). Dynamic Analysis of Nuclear Reactor by Considering Soil Structure Interactions. International Journal of Earth Sciences and Engineering, 11

[10] Qiang XU, J. C. (2015). Dyanmic Analysis Of AP1000 Shield Building Considering Fluid Structure Interations. Nuclear Engineering And Technology , 13.

[11] ASCE, 2007. Seismic Rehabilitation of Existing Buildings, ASCE 41-06, Structural Engineering Institute, Reston, VA.

[12] IS 1786:(2008) High strength deformed steel bars and wires for concrete reinforcement specification

[13] IS 383-(1970) Specification for coarse and fine aggregate from natural source for concrete.

[14] IS 1893:(2002) Criteria for earthquake resistant design of structures

[15] 875 part1:(1997) Code of practise for design loads (Other than earthquake) for buildings and structures

[16] 875 part3:(1987) Code of practise for design loads (Other than earthquake) for buildings and structures

[17] FEMA 451B NEHRP recommended provisions for new building and other structures: training and instructional materials.

[18] IS 456:(2000) Plain and reinforced concrete code of practise

\section{AUTHOR PROFILE}

${ }^{1}$ Niteesh H. M.TECH Student ofcivil Department M .S RamaiahUniveristy of Applied Science.

${ }^{2}$ Dr.Rajashekar Swamy Professor and Head of civil Department M .S RamaiahUniveristy of Applied Science

${ }^{3}$ Santhosh H. P. Assistant Professor of civil DepartmentM .S RamaiahUniveristy of Applied Science 